Alignment: Journal of Administration and Educational Management

Volume 1, Nomor 2, Desember 2018

e-ISSN : 2598-5159

$p-I S S N$ : 2598-0742

DOI : https://doi.org/10.31539/alignment.v1i2.346

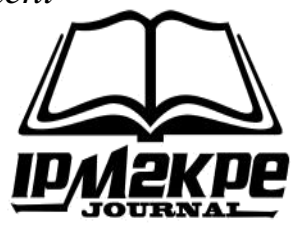

\title{
PENGELOLAAN SANTRI DI SEKOLAH MENENGAH ATAS PONDOK PESANTREN MODERN AL-IKHLAS LUBUKLINGGAU
}

\author{
Hamdan \\ STKIP PGRI Lubuklinggau \\ Hamdangh123@gmail.com
}

\begin{abstract}
ABSTRAK
Tujuan penelitian untuk megetahui pengelolaan santri di Sekolah Menengah Atas Pondok Pesantren Modern Al-Ikhlas Lubuklinggau. Metode yang digunakan dalam penelitian ini adalah metode penelitian deskriptif dengan pendekatan kualitatif. Hasil penelitian, pengelolaan santri dimulai dari pembentukan panitia, penyebaran brosur, seleksi penerimaan santri baru, pengasuhan santri di asrama dan administrasi santri. Semua komponen pengelolaan tersebut telah dikelola sesuai dengan fungsi-fungsi manajemen. Simpulan, pengelolaan santri meliputi; pengelolaan input santri, pengawasan, mematuhi tata tertib, metode (tilawah, tazkiyah dan ta`limah).
\end{abstract}

Kata Kunci: Pengelolaan, Santri, Pondok Pesantren

\begin{abstract}
The aim of the study was to know the islamic boarding school students management in modern Islamic senior high school Al-Ikhlas Lubuklinggau. The method used was qualitative descriptive method. The results presented committees formation, brochures distribution, new students selection, students guidance, and students administration. The whole elements were organized well based on the function. In conclusion, students management include students input management, supervising, obeying the rules, the teaching methods (tilawah, tazkiyah and ta`limah).
\end{abstract}

Keywords: Management, Student, Islamic Boarding School Students 


\section{PENDAHULUAN}

Memasuki abad XXI ditandai dengan era globalisasi yang di dalamnya merupakan dunia informasi, proses komunikasi berjalan semakin intensid sehingga batas-batas negara tidak lagi menjadi penghalang dalam proses transformasi teknologi dan informasi. Dunia pada abad ini akan mengalami transformasi dalam segala aspek kehidupan manusia, social, budaya dan politik. Proses transformasi itu dapat dirangkum dengan istilah globalisasi. Dalam era globalisasi ini kehidupan umat manusia, sebagian sudah dapat diramalkan arahnya, namun sebagian besar masih merupakan teka-teki. Banyak pakar telah menelaah globalisasi, seperti Ali (2003) yang mengidentifikasi enam kekuatan yang mendorong proses tersebut, yaitu : globalisasi dari proses industrialisasi dan teknologi, globalisasi keuangan, komunikasi dan informasi, globalisasi kekaryaan, pekerjaan dan migrasi, globalisasi efek polusi biosfer terhadap kehidupan manusia, globalisasi dari perdagangan persenjataan dan globalisasi kebudayaan, konsumsi dan media massa.

Pendidikan merupakan salah satu kebutuhan pokok manusia dan merupakan pembeda antara makhluk-makhluk lainnya yang hidup di dunia ini. Pendidikan dilakukan dengan tujuan tertentu sesuai dengan cita-cita masyarakat yang membentuknya sehingga selesai pendidikan diharapkan anak didik telah memiliki kemampuan, keterampilan dan kesiapan untuk bersaing dimasa yang akan datang.

Pendidikan sumber daya manusia mempunyai peranan penting bagi kesuksesan dan kesinambungan bangsa Indonesia. Oleh karena itu pendidikan dan peningkatan kualitas sumber daya manusia Indonesia mutlak diperlukan. Pendidikan memiliki posisi strategis dalam pembangunan sumber daya manusia, pendidikan pada dasarnya merupakan proses pencerdasan kehidupan bangsa dan pengembangan manusia seutuhnya.

Tujuan yang hendak dicapai dalam pendidikan Islam terdiri dari tiga aspek yaitu pertama aspek individu yang berkaitan dengan pribadi dan pelajaran mereka berikut perubahan tingkah laku yang diupayakan dalam pendidikan itu. Kedua, aspek social, berkaitan dengan kehidupan masyarakat secara keseluruhan. Ketiga, aspek profesional yang berkaitan dengan pendidikan dan pengajaran sebagai ilmu, senior, profesi dan sebagai suatu aktivitas dalam masyarakat (Yunus, 1990).

Sejak kedatangannya di Indonesia Islam telah menggunakan dakwah dan pendidikan sebagai sarana untuk mensosialisasikan ke tengah masyarakat. Dalam proses mensosialisasikan Islam melalui pendidikan selain didukung oleh masyarakat sendiri juga didukung oleh Pemerintah atau sekurang-kurangnya mendapatkan bantuan dari Pemerintah (Ghozali, 2000)

Keberadaan pondok pesantren sebagai lembaga pendidikan Islam tertua di Indonesia telah berkembang sejak masa penyebaran Islam dan telah banyak berperan dalam mencerdaskan kehidupan masyarakat. Sejalan perkembangan pondok pesantren menunjukkan bahwa lembaga ini tetap eksis dan konsisten 
sehingga dari pesantren lahirlan para kader ulama, guru agama, mubalig yang sangat dibutuhkan di masyarakat.

Perubahan besar yang berjalan dengan teramat cepat melanda kehidupan masyarakat bangsa, dan Negara tersebut yang memaksa kita mempersiapkan diri agar dapat tetap survive dalam kehidupan global yang penuh persaingan sehingga menuntut kerja keras dan hasil kerja yang berkualitas tinggi, tetapi juga bagaimana kita mengembangkan jati diri atau identitas kita sebagai bangasa Indonesia. Hal ini menuntut kita mempunyai wawasan masa depan, yaitu berwawasan abad XXI. Masa depan bukan sesuatu yang menakutkan sehingga harus dihindari, tetapi merupakan peluang untuk meningkatkan taraf kehidupan kita asal kita siap menghadapinya. Menghadapi era globalisasi diperlukan visi yang dapat mengarahkan misi, rencana dan segala ikhtiar. Minimal ada enam komponen yang akan menentukan perubahan yaitu : adanya visi yang jelas, misi merupakan rumusan langkah-langkah kunci untuk mulai melakukan inisiatif, mengevaluasi dan mempertajam bentuk kegiatan untuk mencapai tujuan yang ditetapkan dalam visi, rencana kerja, sumber daya, keterampilan profesional dan motivasi dan insentif.

Peningkatan kemampuan intelektual termasuk penguasaan, penerapan dan pengembangan ilmu pengetahuan serta teknologi agar penguasaan tersebut dapat meningkatkan kualitas hidup manusia Indonesia. Selanjutnya manusia Indonesia yang berkualitas mempunyai daya saing yang tinggi di tengah-tengah kehidupan global. Sudah tentu penguasaan intelektual tersebut selalu harus seimbang dengan peningkatan kemampuan etis dan moral serta agama sebagai sumber nilai-nilai etika moral.

Lembaga pendidikan pesantren sangat relevan untuk mewujudkan tujuan pendidikan nasional tersebut, karena selama ini lembaga pendidikan pesantren memiliki keunggulan tertentu, seperti: sikap disiplin, sikap sosial, sikap moral, dan sikap loyal (Dawan, 2008). Dalam sistem pendidikan pesantren modern, terdiri atas unsur : kiyai, santri, pondok, masjid sistem nilai, madrasah, koperasi tempat keterampilan, dan lapangan olah raga, atau sering disebut pesantren terpadu atau pesantren alternatif. Dalam pesantren modern tidak hanya mendidikan calon kiyai tetapi kiyai plus yaitu ulama intelektual dan intelektual ulama. Para santri itu memiliki keterampilan dan bervariasi sebagai bekal kehidupan pada masa depan ditengah-tengah masyarakat kelak.

Pengelolaan sekolah akan efektif dan efisin apabila didukung oleh sumber daya manusia yang profesional untuk mengoperasikan sekolah, kurikulum yang sesuai dengan tingkat perkembangan dan karakteristik siswa, kemampuan dan commitment (tanggung jawab terhadap tugas) tenaga kependidikan yang handal, sarana prasarana yang memadai untuk mendukung kegiatan belajar mengajar, dana yang cukup untuk menggaji staff sesuai dengan fungsinya, serta partisipasi masyarakat yang tinggi. Bila salah satu hal di atas tidak sesuai dengan yang 
diharapkan dan / atau tidak berfungsi sebagaimana mestinya, maka efektivitas dan efisiensi pengelolaan sekolah kurang optimal.

\section{METODE PENELITIAN}

Metode yang digunakan dalam penelitian ini adalah metode penelitian deskriptif dengan pendekatan kualitatif. Hal ini dilakukan karena sesuai dengan karakteristik penelitian kualitatif yang dikemukakan oleh Mile dan Huberman (1994) penelitian kualitatif memiliki latas alamiah sebagai sumber data langsung dan peneliti adalah instrument kunci, 2) peneliti Kualitatif bersifat deskriptif, 3) peneliti kualitatif lebih menekankan pada proses bukan pada hasil, 4) pendekatan kualitatif cenderung menganalisis data secara indultif, dan 5) makna merupakan perhatian utama dalam pendekatan penelitian kualitatif.

Penelitian jenis ini untuk mengeneralisasikan kategori dalam rangka memahami fenomena manusia,terutama dalam melihat atau mengamati segala sesuatu yang ada, dalam bahasa yang seloyal mungkin tentang perasaan dan pengalaman mereka atau mengamati orang lain dalam lingkungannya. Dalam konteks penelitian ini adalah untuk mengamati, mensepsikan dan menginterprestasikan tindakan-tindakan para pelaku pendidikan di pondok pesantren.

Jadi penelitian ini tidak bertujuan untuk membuktikan hipotesisnya diterima atau ditolak tapi hanya di tekankan pada pengumpulan data untuk mendeskripsikan keadaan sesungguhnya yang terjadi di lapangan.Penelitian jenis ini digunakan untuk menjeneralisasi kategori dalam rangka memahami fenomena manusia terutama dalam melihat atau mengamati segala sesuatu yang di dalam orang, dalam bahasa yang seloyal mungkin tentang perasaan dan pengalaman mereka atau mengamati orang lain dalam lingkungannya. Dalam kontek ini adalah untuk mengamati, mensepsikan dan menginterprestasikan tindakantindakan para pelaku pendidikan di Pondok Pesantren Modern Allkhlas Kota Lubuklinggau.

Sebelum memilih penelitian ini, persiapan yang dilakukan adalah 1) memilih topik permasalahanyang akan diteliti, 2) melakukan penjajakan dan pendekatan terhadap lembaga dan subjek peneliti untuk memperoleh data awal sehingga mendapat ganmbarann yang lengkap dan jelas mengenai masalah yang akan diteliti, 3) melakukan pendalaman materi bacaan yang berhubungan dengan masalah penelitian, 4) penyusunan desin penelitian serta kisi-kisi pengumpulan data dan pedoman wawancara, dan 5) pengurusan surat ijin peneliti.

\section{HASIL DAN PEMBAHASAN}

Hasil penelitian menunjukkan beberapa hal sebagai berikut: pertama, rekruitmen santri SMA mulai awal berdirinya pondok pesantren Modern sampai saat ini dilakukan secara bersama-sama dengan yayasan, lembaga pendidikan dan pengasuhan pondok pesantren modern membentuk panitia penerimaan santri baru 
yang disahkan oleh YPP. Yayasan pendidikan dan pengajaran Al Ikhlas yang menaungi Pondok Pesantren Modern Al Ikhlas dalam kepanitian santri baru juga melibatkan para santri senior yang menjadi pengurus organisasi santri. Berdasarkan jawaban responden Drs.H. Rudy Hartoyo, M.Pd Kepala Sekolah SMA Al Ikhlas mengatakan bahwa penerimaan santri dilakukan persiapan terlebih dahulu.

Proses kegiatan rekuitmen santri baru adalah sebagai berikut : pertama, pembentukan panitia penerimaan santri baru, kedua sosialisasi dan publikasi tentang penerimaan santri baru, ketiga, penerimaan santri baru, keempat, penyaringan penerimaan santri baru, kelima pengumuman hasil seleksi dengan dilanjutkan daftar ulang, keenam pelaksanaan pekan orientasi santri baru.

Masalah seleksi dalam penerimaan santri baru tidak bertujuan menentukan kelulusan santri tetapi bertujuan melihat kemampuan setiap santri yang masuk, persyaratan untuk menerima santri baru adalah calon santri diantar langsung oleh oranga tua/wali. Berijazah SMP/MTS untuk masuk ke SMA, sehat jasmani dan rohani, mampu tinggal di asrama dibuktiktikan dengan surat keterangan dokter, pas poto 3 x 4 sebanyak 10 lembar dan 2 x 3 sebanyak 8 lembar, foto copy STTB yang dilegalisir 3 lembar, dua map plastik dan dua map karton (brosur pondok:2011). Setiap santri yang mendaftar harus ikut seleksi tertulis dan praktek. Kedua, seluruh santri SMA wajib menginap di asrama yang disiapkan oleh pondok,

Pengaturan santri di asrama adalah tugas dari bidang pembinaan dan pengasuhan santri. Namun sebagai upaya mempermudah kinerja pengasuhan santri, Pondok pesantren Modern Al Ikhlas menunjuk dan mengangkat beberapa orang wakil pimpinan pondok bidang pengasuhan sebagai penanggung jawab penuh operasional pengasuh santri. Yang mengatur dan mengawasi santri di asrama adalah para Kepala asrama pondok masing - masing sesuai dengan kelas masing - masingdi asrama. Dalam menjalankan tugasnya dibantu oleh tenaga pengasuhyang terdiri dari staf edukatif, karyawan dan santri tenaga pengabdian yang menetapkan atau tinggal di dalam komplek pondok pesantren.

Disamping itu dalam pelaksanaan program kerja pengasuh dan pembimbing santri wali pondok juga dibantu oleh pengurus organisasi pengurus pondok pesantren Modern Al Ikhlas (OP3M) yang mana pengurusnya terdiri dari santri yang sudah senior pilihan, diangkat dan dilantik langsung oleh pimpinan pondok pesantren.Mengenai fasilitas yang tersedia di setiap kamar untuk para santri yaitu tempat tidur ranjang bisa muat 10 orang santri sementara kasur,lemari sudah disediakan oleh pondok, sementara itu untuk mandi telah di siapkan tempat pemandian umum dan WC.

Penempatan santri di asrama dipisahkan antara kelas, masing-masing kelas dihuni oleh beberap orang dan didampingi oleh santri senior dan dibimbing oleh ustadz pembimbing. Untuk merealisasikan visi dan misi pendidikan di Pondok Pesantren Modern Al Ikhlas Kota Lubuklinggau maka diaturlah kegiatan santri, 
adapun kegiatan santri sudah dirumuskan dan mempunyai tahapan-tahapan yang sudah disepakati, tahapan-tahapan tersebut antara lain :tahapan kegiatan dan daur pembinaan antara lain: 1)memberikan landasan nilai sebagai pedoman, koreksi dan peneguhan, 2) melatih keterampilan sesuai landasan nilai yang diberikan, 3) menyediakan lingkungan yang mencerdaskan, 4) memberikan pendampingan dan kontrol berkelanjutan, 5) mengevaluasi pencapaian (untuk mengulang daur jika kurang berhasil atau meningkatkan level jika berhasil).

Ketiga,Santri yang telah tamat dianjurkan melanjutkan kuliah S1 ke perguuruan baik itu Negeri ataupun swasta. Bagi santri yang tidak lulus UN akan diikutkan ujian ke Paket $\mathrm{C}$ dan akan dianjurkan kuliah ke Perguruan Tinggi yang mempunyai hubungan dengan SMA Al Ikhlas. Santri yang tidak berminat kuliah diberdayakan di pesantren menjadi pengasuh di asrama dan bagi santri yang akan pulang ke tempat asalnya, dianjurkan untuk mengamalkannya di kampung tempat tinggalnya masing-masing. Apa saja kriteria santri yang akan kuliah di perguruan tinggi yang dibiayai oleh lembaga? "1. mempunyai keahlian dalam bidang ilmu tertentu (bakat) sehingga lembaga harus memfasilitasi untuk menunjang terlaksananya pendidikan lanjutan anak tersebut, 2. mempunyai loyalitas kepada lembaga dan dakwah, 3. mempunyai kemitraan dan siap diberi amanah oleh lembaga.

Keempat, faktor pendukung dalam menjalankan pengelolaan santri di SMAAl Ikhlas antara lain: 1) letak strategis di depan pusat perdagangan atau mol, 2) Fasilitas pondok yang relatif lengkap, 3) lokasinya luas yaitu 5,6 ha, 4) terletak di tengah pemukiman penduduk, (diapit 2Hotel), 5) didukung pemerintah sangat tinggi dengan keberadaan Pondok karena pondok Pesantren Modern Al Ikhlas telah ikut membantu pembangunan daerah dalam bidang pendidikan, dan pembinaan kehidupan sosial berupa keteladanan, 6) pengelolaan pondok yang terbuka kepada siapa saja yang akan masuk di wilayah pondok dilayani, 7) sumber daya manusia mulai dari tenaga pengajar, staf, pengelola, kepala sekolah semuanya masih muda-muda dan enerjik, 8) dengan diterapkan syariat Islam di lingkungan pesantren adalah salah satu faktor pendukung untuk menanamkan kedisiplinan baik itu anak maupun warga lingkungan di pondok.

Faktor penghambat pelaksanaan pengelolaan santri ialah 1) minimnya dana pengelolaan 2) SDM yang sangat terbatas 3) Input Santri yang masuk ke SMU bahan mentahnya sangat lemah (fakir miskin, yatim piatu, anak-anak terlantar) 3) Kediaman wali santri sangat jauh dari pondok mengakibatkan sulit untuk komunikasi dan berkoordinasi dengan orang tua.Menurut Afandi (2003:5) , unsure-unsur penting dalam pengelolaan pesantren adalah : a) Misi pesantren yang sesuai dengan filosofi pendidikan Islam , b) Struktur Organisasi fungsional pesantren secara proposional dan Profesional , c) Kemitraan dan pelayanan yang baik terhadap santri, orang tua santri dan masyarakat, d) perencanaan dan pengembangan pesantren secara efektif dan terbuka untuk menjaga citra pesantren sebagai media pendidikan murah masyarakat umum, e) pengelolaan dan supervise 
sumber daya manusia yang efektif, f) dinamika dalam menjalankan strategi pembelajaran untuk meningkatkan mutu pendidikan pesantren g) penguatan kurikulum praktis, sesuai dengan disiplin keilmuan pesantren yang serba praktis untuk menunjang peningkatan amaliah ubudiah santri dan masyarakat, h) pengelolaan sumber daya belajar secara efisien, i) Pengelolaan dan Pemeliharaan fasilitas pesantren secara baik dan efektif dan j) system evaluasi dan pertanggungjawaban yang teratur berdasarkan indicator keberhasilan pesantren.

Kelima, dalam rangka untuk memperbaiki dan meningkatkan mutu pendidikan di SMA Al Ikhlas program pesantren adalah 1) memberikan peluang bagi para pengurus, baik itu pengurus yayasan, kepala sekolah ataupun guru diberikan beasiswa untuk melanjutkan pendidikan ke jenjang yang lebih tinggi dari Diploma ke S1 dan dari S1 ke S2 2) sementara itu bagi santri sebagai kader lembaga yang berkeinginan untuk melanjutkan ke S1 difasilitasi oleh lembaga dengan beasiswa penuh, 3) tetapi bagi santri yang tidak berkeinginan untuk melanjutkan pendidikan ke S1, lembaga mempersiapkan suatu program pendidikan percepatan 3 bulan yaitu Tradribu dua'ad. 4) pelatihan bagi guruguru, Kepala Sekolah, pengurus dan warga tentang manajemen pendidikan, pengelolaan pendidikan, teknik mengajar, dan motivasi. Dan mendatangkan Instruktur Nasional. Pelatihan ini biasa dilaksanakan satu semester sekali.

Pengelolaan santri di sekolah menengah atas pondok pesantren modern AlIkhlas telah berjalan dengan baik,maka perlu ditingkatkan dengan cara melaksanakan penerimaan santri baru telah sesuai dengan manajemen santri. Proses kegiatan rekrutmen santri baru adalah sebagai berikut: pertama, pembentukan panitia penerimaan santri baru, kedua sosialisasi dan publikasi tentang penerimaan santri baru, ketiga penerimaan santri baru, keempat penyaringan/ ujian penerimaan santri baru, kelima pengumuman hasil seleksi dengan dilanjutkan daftar ulang, keenam pelaksanaan pekan orientasi santri baru.

Menurut Mashud (2003) langkah-langkah penerimaan santri baru pada garis besarnya adalah a. pembentukan panita penerimaan santri baru, b. menentukan syarat pendaftaran calon, c. menyediakan formulir pendaftaran, d. pengumuman pendaftaran calon, e. menyediakan buku pendaftaran, f. waktu pendaftaran dan g. pengumuman calon yang diterima. Menurut Mashud (2003) Pengelolaan atau manajemen kesiswaan merupakan kegiatan-kegiatan yang bersangkutan dengan masalah kesiswaan di sekolah. Tujuan manajemen kesiswaan adalah menata proses kesiswaan mulai dari perekrutan, mengikuti pembelajaran sampai dengan lulus sesuai dengan tujuan instruksional agar dapat berlangsung secara efektif dan efisien. Kegiatan Pengelolaan kesiswaan meliputi: perencanaan, penerimaan santri baru, pembinaan santri dan keluluusan. Kemudian penerimaan santri baru merupakan proses pelayanan dan pencatatan siswa dalam penerimaan santri baru, setelah melalui seleksi masuk siswa baru dengan persyaratan-persyaratan yang telah ditentukan. 
Dalam penerimaan siswa baru terdapat beberapa kegiatan yang dilaukan seperti (1) penetapan daya tampung, (2) penetapan persyaratan siswa yang akan diterima, dan (3) pembentukan panitia penerimaan santri baru.Persyaratan untuk penerimaan santri baru adalah calon santri diantar langsung oleh orang tua/ wali. Berijazah SMP/MTS untuk masuk SMA, sehat jasmani dan rohani, mampu tinggal di asrama dibuktikan dengan surat keterangan dokter, paas photo $3 \mathrm{x} 4$ sebanyak 10 lembar, dan 2 x 3 sebanyak 8 lembar, fotocopy STTB yang dilegalisir 3 lembar, dua map plastik dan dua map karton ini sudah cukup lengkap.

Menurut Suryosubroto (2004) mengatakan bahwa syarat pendaftaran untuk SLTP dan SLTA secara umum adalah a. surat keterangan kelahiran, b. surat keterangan kesehatan, c. surat keterangan baik dari kepala sekolah asal, d. salinan tanda lulus yang disyahkan, e. salinan raport kelas tinggi, f. membayar biaya pendaftaran, g. pas photo dan, 6. mengisi formulir pendaftaran. Menurut Mashud (2003) untuk mencapai tujuan pendidikan diperlukan proses. Proses ini dimulai dari perencanaan, pengorganisasian, pengarahan, pemantauan dan penilaian. Perencanaan meliputi kegiatan menetapkan apa yang ingin dicapai, bagaimana mencapai, berapa lama, berapa orang yang diperlukan dan berapa banyak biayanya.

Perencanaan itu dibuat sebelum suatu tindakan dilaksanakan. Pengorganisasian diartikan sebagai kegiatn membagi tugas-tugas kepada orang yang terlibat dalam kerjasama pendidikan tadi karena tugas-tugas ini demikian banyak dan tidak dapat diselesaikan oleh satu orang saja, maka tugas-tugas ini dibagi untuk dikerjakan masing-masing anggota organisasi. Pengkoordinasikan mengandung makna menjaga agar tugas-tugas yang telah dibagi itu dapat dikerjakan menurut kehendak yang mengerjakan saja, tetapi menurut aturan sehingga menyumbang terhadap pencapaian tujuan yang telah ditetapkan dan disepakati. Tiap-tiap orang harus mengetahui tugas-tugas masing-nasing sehingga tumpang tindih yang tidak perlu dihindarkan.

Disamping itu dalam menjalankan tugas pendidikan, pengaturan waktu merupakan hal penting. Ada kegiatan yang harus didahulukan, ada yang harus didahulukan dan ada juga yang harus secara bersamaan. Hal ini berarti secara umum masalah penerimaan santri baru yang merupakan bagian dari manajemen santri telah dilaksanakan dengan baik dan sesuai dengan manajemen santri. Dalam penerimaan santri telah dilakukan perencanaan dengan diawali pembentukan panitia penerimaan santri baru (PSB) dan diakhiri dengan pengumuman, serta dilakukan pengorganisasiian yang baik ditunjukkan dengan tahap-tahap kegiatan yang jelas.Dalam penerimaan santri belum dilakukan pengawasan mutu yang baik. Seleksi yang dilakukan hanya untuk melihat kemampuan santri agar dilakukan pendidikan yang tepat, bukan untuk menyaring santri yang berkualitas.

Menurut Mashud (2003) manajemen pendidikan dapat dilihat dengan kerangka berpikir system. Dalam melihat pondok pesantren sebagai suatu system kita harus melihat: a. masukannya yaitu bahan mentah yang berasal dari luar 
sistem (lingkungan) yang akan diolah oleh system, dalam system (lingkungan) yang akan diolah oleh sistem, dalam sistem sekolah dasar masukan ini adalah anak-anak yang masuk ke pondok pesantren, b) prosesnya, yaitu kegiatan pondok pesantren untuk mengolah masukan menjadi keluaran. Untuk melaksanakan proses ini harus ada sumber, baik tenaga sarana maupun prasarana, uang maupun waktu, c. keluaran yaitu masukan yang telah diolah melalui proses tertentu dalam hal ini berupa lulusan.Mutu lulusan akan sangat tergantung kepada mutu masukan, masukan instrumen dan proses itu sendiri. Dengan demikian kemampuan awal santri, latar belakang santri, keadaan orang tua santri sebagai masukan mentah. Mutu juga oleh mutu guru, mutu sarana dan prasarana, mutu dan iklim kerja sama di antara guru dengan santri, guru dengan guru dengan kepala sekolah dan kepala pondok.

Menurut Dewam (2008) bila Anda ingin menjadi manajer yang ri'ayah (berjiwa pemimpin): a. berikan perhatian atau kepedulian kepada bawahan, b. buat perencanaan kerja yang baik, c. bersungguh-sungguh dan teliti dalam melaksanakan rencana kerja, d. lakukan pengawasan secara terus menerus, e. lakukan evaluasi hasil secara berkala, f. tegakkan disiplin dalam waktu kerja, g. memikul tanggung jawab terhadap hasil akhir.Berkenaan dengan proses pembinaan santri pesan pendiri Pondok Pesantren Modern Al-Ikhlas K.H. Drs.M.Syueb Tamat (Alm) bahwa pembinaan santri harus dilandasi dengan AlQur'an Surat Al-Jum'ah ayat 2 yang terdiri dari:Metode TilawahYaitu suatu aktivitas pendidikan yang seluruh kegiatan santri merupakan proses pencarian dan pengenalah TUHAN.

Dengan kerja fisik dan berfikir keras mereka diantarkan untuk merasakan kelemahan/ keterbatasan dirinya dan mengakui kekuasaan Allah. Dengan memahami eksistensi manusia (dirinya sendiri) dan penciptaan alam semesta, mereka dihantarkan untuk merasakan adanya Allah dalam seluruh akvitivitas hidupnya. Akhir dari perjalanan tilawah yaitu lahirnya suatu pernyataan yang penuh kesadaran sebagai pengakuan bahwa TIDAK ADA TUHAN SELAIN ALLAH yang dikenal dengan kalimat tauhid LA ILA HA ILLALLAH.

Proses yang dilakukan pada pendekatan tilawah ini disesuaikan menurut tingkat pemahaman para santri.Metode Tazkiyahyaitu aktifitas pengecekan atau evaluasi akan benarnya dan berfungsi dan berperannya pernyataan syahadat itu. Dan dapat ditandai dengan lahirnya penyesalan atas seluruh kesalahan yang pernah dilakukan para santri / siswa lewat ungkapan dalam berbagai kesempatan dan ditandai dengan usaha keras membuang dan mengikis lima macam penghalang berfungsi dan berperannya syahadat, yaitu warna dasar yang dimiliki oleh manusia yang selalu memberikan dorongan dan rangsangan bahwa merasa mampu dan hebat, pantang disinggung, maunya dipuji dan disanjung, berwatak sombong dan angkuh. Sifat thagha inilah yang sering melahirkan persaingan dalam bentuk permusuhan yang menyebabkan timbulnya malapetaka dan musibah 
berupa pembunuhan sebagai tindak lanjut mental sadis dan kriminal yang mereka miliki.

Oleh sebab itu salah satu sifat yang harus ditumbuhkan dalam diri santri dan dalam membantu mereka untuk membuang, mengikis sifat thagha dan seluruh cabang-cabangnya adalah kejujuran dan ketaatan dalam diri mereka. Sebagai modal pertama untuk mengetahui adanya kejujuran dan ketaatan diadakan tes alamiah, yaitu memberikan suatu kegiatan fisik menurut ketentuan yang berlaku dibawah pengawasan instruktur lapangan yang ditunjuk. Selain cara tersebut kepatuhan mereka dalam melaksanakan seluruh tata cara peribadatan mendapat pengawasan dapat perhatian khusus. (Q.S : Al-Alaq 6-7 dan Q.S An-Nahl 22-23). Cinta Dunia, setiap orang yang belum mengerti fungsi dan hakekat benda atau materi dan belum mengenal, memahami peran Tuhan dalam hidupnya dipastikan mereka akan menjadi pencinta dunia atau hamba dunia antara lain tanda-tandanya adalah orientasi berfikir selalu kepada dunia dan kesibukan hidupnya adalah urusan dunia (materi ).

Untuk membuang dan mengikisnya dari para santri dikenalkan hakekat dan fungsi kehidupan di dunia berikut bahayanya dan mengenalkan kepada mereka peranan Tuhan. Mereka dibiasakan untuk tidak punya kepentingan dengan uang, dan tidak punya ketergantungan kepada harta benda, artinya uang dan harta tidak memberikan pengaruh, sama saja antara ada atau tidaknya, tidak merasa bangga karena punya uang dan tidak merasa hina apabila tidak punya uang, tidak boleh hanya menghormati kepada yang berharta dan berpangkat sementara memandang rendah kepada orang farkir miskin.

Para santri dibiasakan untuk merasa bangga sebagai orang beriman dan berTuhan (QS. Attaubah : 24 \& 38, QS. Annajem : 29-30, QS Ali-Imran : 14, QS. An-Nahal: 105-107), Dominan Nafsu, sifat nafsu tidak pernah merasa puas dan tidak pernah merasa miskin dari sekian banyak tumpukan keinginan yang tidak akan pernah tercapai. Keinginan nafsu itu maunya yang enak, bebas, santai, keinginannya dan kemauannya pantang dibatasi. Untuk mengikis dan mencegah dominasi nafsu pada setiap santri, maka kegiatan santri diarahkan secara produktif dan bermanfaat dengan kegiatan yang padat (QS. Al-Araf: 175-177 dan QS. Assayans: 7-8 ).

Tumpukan dosa, setiap kesalahan yang dilakukan manusia akan menimbulkan noda pada dirinya, dan apabila dibiarkan maka akan menjadi tumpukan kesalahan. Tumpukan itulah yang akan berproses menjadi watak kepribadian dan sifat mental kriminal dan bromocorah yang mendatang keresahan. Untuk menimbulkan kesadaran dalam diri setiap santri terhadap kesalahan yang harus mereka laksanakan, (1) jujur mengakui kesalahan yang pernah mereka perbuat kemudian beristiqfar memohon ampunan kepada Allah minimal seratus kali setiap hari, (2) memperbanyak dzikir kepada Allah dan memperbanyak sujud sebagai salah satu tanda menyerah dan menyesal, (3) memperbanyak pengorbanan baik waktu senang maupun waktu susah, moril 
maupun materil, (4) menahan diri dari marah dan kejengkelan, (5) memaafkan kesalahan orang lain dan membalas dengan berbuat baik kepadanya, (6) apabila terlanjur melakukan dosa, kesalahan, mereka tidak menunda untuk segera menyatakan penyesalannya kemudian mengiringinya dengan kebaikan berupa dzikir, ibadah dan kerja keras (amal saleh), (7) tidak mempertahankan budaya, kebiasaan hidup mereka yang keji, bertentangan dengan agama sedangkan mereka mengetahuinya. (QS. Al-Anam : 120, QS. Al-Jatsiayah : 7-8, QS. Al-Imran : 133135).

Dalam pengelolaan lulusan santri disesuai dengan visi dari Pondok Pesantren modern Al Ikhlas adalah mencetak kader-kader Islam yang nantinya akan disebar ke daerah-daerah dalam rangka untuk memberikan pencerahan kemasyarakat tentang Islam. Untuk merealisasikan visi dan misi pondok maka pengelolaan santri yang tamat dari SMA harus diperhatikan.Santri yang tamat dari SMA akan dikuliahkan ke Perguruan Tinggi dengan Bea Siswa yang nantinya akan menjadi kader dan siap ditempatkan dimana saja sesuai dengan SK tugas dari lembaga. Tetapi untuk masuk ke Perguruan Tinggi harus melewati test dan syaratnya, santri harus lulus dari SMA baik dari Diknas maupun materi ke pesantrenan yang berupa pelajaran Diniyah.

SMA Al Ikhlas tidak melaksanakan program pengabdian , para santri yang telah lulus mengikuti test ke Perguruan Tinggi langsung dikirim ke tempat mereka lulus.Untuk faktor Pendukung dan Penghambat Pelaksanaan Pengelolaan Santri, ada beberapa faktor yang dapat berperan sebagai pendukung pelaksanaan pengelolaan santri, yaitu : 1) letak strategis yaitu jalan lintas Sumatera, letaknya di tengah kota, 2) Fasilitas Pondok yang relative lengkap, 3) Lokasinya luas yaitu $5,8 \mathrm{Ha}$ sangat memadai untuk kegiatan ekstrakurikuler santri, dan untuk perkebunan dan pertanian, 4) terletak ditengah pemukiman penduduk, diapit 2 hotel sehingga tidak merasa kesunyian dan tidak terpencil suasana kota masih bisa dinikmati, 5) pemerintah setempat merasa diuntungkan bahwa pondok pesantren modern Al Ikhlas telah ikut membantu pembangunan daerah dalam bidang pendidikan, keamanan, dan kehidupan sosial berupa keteladanan. 6) akan masuk diwilayah pondok dilayani, 7) sumber daya manusia mulai dari tenaga pengajar, staf, pengelola, kepala sekolah semuanya masih energik yaitu umumnya sarjana pada bidang studinya masing-masing, 8) dengan diterapkan syariat Islam di lingkungan pesantren adalah salah satu faktor pendukung untuk menanamkan kedisiplinan baik itu anak maupun warga lingkungan di pondok.

Banyaknya santri yang masuk ke pondok pesantren adalah suatu tolak ukur bahwa pondok tersebut berkualitas sehingga mampu bersaing dengan sekolah umum lainnya. Untuk Faktor Penghambat dalam pelaksanaan pengelolaan santri ialah 1) minimnya dana pengelolaan 2) SDM yang sangat terbatas 3) Input Santri yang masuk ke SMA bahan mentahnya sangat lemah (fakir miskin, yatim piatu, anak-anak terlantar) 3) Kediaman wali santri sangat jauh dari pondok mengakibatkan sulit untuk komunikasi dan berkoordinasi dengan orang tua. 
Menurut Dawam (2008) unsur-unsur penting dalam pengelolaan pesantren adalah : a) Misi pesantren yang sesuai dengan filosofi pendidikan Islam , b) Struktur Organisasi fungsional pesantren secara proposional dan Profesional , c) Keitraan dan pelayanan yang baik terhadap santri, orang tua santri dan masyarakat, d) perencanaan dan pengembangan pesantren secara efektif dan terbuka untuk menjaga citra pesantren sebagai media pendidikan murah masyarakat umum, e) pengelolaan dan supervise sumber daya manusia yang efektif, f) dinamika dalam menjalankan strategi pembelajaran untuk meningkatkan mutu pendidikan pesantren g) penguatan kurikulum praktis, sesuai dengan disiplin keilmuan pesantren yang serba praktis untuk menunjang peningkatan amaliah ubudiah santri dan masyarakat, $h$ ) pengelolaan sumber daya belajar secara efisien, i) Pengelolaan dan Pemeliharaan fasilitas pesantren secara baik dan efektif dan j) system evaluasi dan pertanggungjawaban yang teratur berdasarkan indicator keberhasilan pesantren.

Adapun upaya untuk memperbaiki dan meningkatkan mutu pendidikan di SMA Al Ikhlas dengan program pesantren adalah 1) memberikan peluang bagi para pengurus, baik itu pengurus yayasan, kepala sekolah ataupun guru diberikan bea siswa untuk melanjutkan pendidikan ke jenjang yang lebih tinggi dari Diploma ke S1 dan dari S1 ke S2 2) sementara itu bagi santri sebagai kader lembaga yang berkeinginan untuk melanjutkan ke S1 difasilitasi oleh lembaga dengan bea siswa penuh, 3) tetapi bagi santri yang tidak berkeinginan untuk melanjutkan pendidikan ke $\mathrm{S} 1$, lembaga mempersiapkan suatu program pendidikan percepatan 3 bulan yaitu Tradribu dua'ad, 4) pelatihan bagi guruguru, Kepala Sekolah, pengurus dan warga tentang manajemen pendidikan, pengelolaan pendidikan, teknik mengajar, dan motivasi.

\section{SIMPULAN}

Pengelolaan santri di SMA pada Pondok Pesantren modern Al Ikhlas telah berlangsung sesuai dengan perencanaan semula. Hal ini mulai dari pembentukan panitia, penyebaran brosur, seleksi penerimaan santri baru, pengasuhan santri di asrama dan administrasi santri. Semua komponen pengelolaan tersebut telah di kelola sesuai dengan fungsi-fungsi manajemen.Kemudian pengelolaan santri meliputi; pengawasan, mematuhi tata tertib, metode (tilawah, tazkiyah dan ta`limah). 


\section{DAFTAR PUSTAKA}

Dawam, A. (2008). Manajemen Madrasah Berbasis Pesantren. Jakarta: Lista Fariska Putra

Gozali, B .(2000). Pesantren Berwawasan Lingkungan. Jakarta: Co Prasasti Imron, A. (2003). Manajemen Pendidikan. Malang: Universitas Negeri Malang Masyhud, M. (2003). Manajemen Pondok Pesantren. Jakarta: Diva Pustaka Karya Miles, M. B., \& Huberman, A. M. (1994). An Expanded Sourcebook Qualitative Data Analysis, Second Edition. New Delhi: Sage Publications

Muhmud, Y. (1990). Sejarah Pendidikan di Indonesia. Jakarta: Nidakarya 